\title{
Director's Age Diversity and Firm Performance: A New Perspective
}

\author{
Mazrah Malek (Corresponding author) \\ Tunku Puteri Intan Safinaz School of Accountancy, Universiti Utara Malaysia \\ 06010 Sintok, Kedah, Malaysia \\ E-mail: mazrah@uum.edu.my
}

\author{
Ayoib Che-Ahmad \\ Tunku Puteri Intan Safinaz School of Accountancy, Universiti Utara Malaysia \\ 06010 Sintok, Kedah, Malaysia \\ E-mail: ayoib@uum.edu.my
}

\author{
Saidatunur Fauzi Saidin \\ School of Economics and Management, Universiti Putra Malaysia \\ 43300 Serdang, Selangor, Malaysia \\ E-mail: saidatunur@upm.edu.my
}

Received: July 5, $2021 \quad$ Accepted: Nov. 17, $2021 \quad$ Published: December 28, 2021

doi:10.5296/ajfa.v13i2.18707 URL: https://doi.org/10.5296/ajfa.v13i2.18707

\begin{abstract}
Diversity of board members has become a recent topic by which it has been linked to board's effectiveness. It can be postulated that directors from a different generation will exhibit different values, knowledge and behavior that can influence the decisions and actions of a firm. However, earlier studies have produced mixed findings on the effect of director's age and firm performance. This study proposes that in order to examine the influence of age diversity, researchers must capture the difference in the age cohort of directors. Different generations carry its own common and unique characteristics. Consistent with the diversity concept, age diversity should be examined based on the inclusion of different generations to
\end{abstract}


the board, and not just the average number of directors' age as practiced in earlier studies.

Keywords: age, diversity, generation, performance 


\section{Introduction}

The collapse of mega corporations such as WorldCom and Enron in the early $21^{\text {st }}$ century can be considered the impetus to corporate governance reforms in many countries including Malaysia. The reformation has been focusing on having 'better' corporate governance by means of 'tidying up' the boardroom (see for example U.S Sarbanes Oxley Act, 2002; Malaysian Code on Corporate Governance, 2017). The early emphasis on board of directors' reform is on enhancing the independence of non-executive directors which is consistent with the monitoring roles of directors. For example, the U.S Sarbanes Oxley Act (2002) has restricted the audit committee from receiving any consulting, advisory and compensatory fee (other than as a director) and must not be an affiliated person of the company or any subsidiary. In Malaysia, the latest Malaysian Code on Corporate Governance (2017) requires independent directors to hold their position for a maximum number of nine (9) years only, among other things. However, the role of directors goes beyond than just their oversight role to management. They are also expected to be actively involved in the company's operations, in order to be able to enhance its performance. For example, as postulated by Hambrick \& Mason (1984), board of directors is also responsible in identifying strategic directions and improving the firm's decision-making. The Malaysian Code on Corporate Governance (2017) also highlighted that the board is also responsible for the long-term success of a company and the delivery of sustainable value to its stakeholders. Furthermore, as the highest internal governance mechanism especially in a unitary board structure, most main decisions are decided at the board level. Top management appointments, internal controls and strategic decisions are among the decisions that require board's approval. Therefore, in recent years, the diversity of board members has received countless attention, not only by researchers but also regulatory bodies and the general public. This is because the perception is that board of directors with diverse backgrounds can enhance the effectiveness of the board and thus, the firm's performance (Abdullah \& Ku Ismail, 2013; Horvath \& Spirollari, 2012; Gavrea \& Stegerean, 2012).

The concept of diversity of the board of directors can be viewed as having a mix of education backgrounds, genders, ethnicities, ages, etc. among the directors (Pechersky, 2016). Each member of the board represents accomplished individuals which can contribute and enhance the decision-making process (Minichilli et al., 2009). Diversity of board members can improve the decisions made by companies, accomplished by having several different perspectives within the board which later may spawn into fruitful discussions and exchange of ideas (Hoffman \& Maier, 1961). This is based on the beliefs that a homogenous group of individuals may have the same perspective and through diversity, they can bring in several inputs. Furthermore, as the responsibility of the board has now expanded to other stakeholders (previously, only shareholders), it stands a strong point that the board should be comprised of representatives of the entire stakeholders (Husey \& Rindova, 2001; Abdullah \& Ku Ismail, 2013). The government, in general has begun to recognize the benefits of diversity, for example in the U.K, regulatory agencies encourage top public listed companies to improve gender diversity on their boards (Goyal, Kakabadse \& Kakabadse, 2019). Meanwhile, several other developed countries, such as the United States and the European Union have now 
required corporations to disclose their board diversity practices considering this (Harjoto, Laksmana \& Lee, 2015). In Malaysia, the Prime Minister has announced on $27^{\text {th }}$ June 2011, a policy of 30-percent women on the board by 2016. However, as noted by Erhardt, Werbel \& Shrader (2003), diversity may be a highly visible effort to demonstrate discrimination, and the effect it has on firm's performance is less clear.

Age is recognized as one distinct characteristic among individuals. Researchers in the past have commonly classified individuals according to different age generations (cohorts) such as traditionalists, baby boom, Generation- $X$, Generation- $Y$ and Generation-Z. At the same time, people of the same age generation have been postulated to have common (among the same generation) and unique (as compared to other generations) characteristics. In a study conducted by the Board Governance Research LLC based in the U.S on the boards of companies within the S\&P 500 in 2017 had found little dispersion in the average of directors in the S\&P 500 companies with an average age of all boards was 62.4 . Within individuall boards, more than half of the S\&P 500 boards have three decades represented on their boards, most commonly directors in their 50s, 60s and 70s. Similar scenario can also be found in Malaysia. An earlier study in Malaysia by Abdullah \& Ku Ismail (2013) of 100 top listed companies for the year 2007 revealed that the minimum average age of the board is 49 , while the maximum age is 68 and the mean is almost 58. It has also been found that almost 75 percent of the board has an average age of between 50 to 59 years old. The study also observed that most boards in Malaysia consisted of middle to retire-aged group members who have previously served as executive directors or ex-government officers, commonly politicians. A later study by Hassan \& Marimuthu (2016) of 60 listed companies between the years 2009 to 2013 had found that the average age of board members is 59; while the lowest is 49 and the highest is 71 . In a more recent study titled 'Detailed Analysis on Malaysia's Top 100 Companies Board Composition' by a private investment firm RHL Ventures based in Malaysia, cited from the Borneo Post (2020) had found that Malaysia's corporate boardrooms lack diversity in gender and age representation. The study had assessed 873 directorships from Malaysia's largest companies (based on market capitalization on Bursa Malaysia) in 2020, whereby examinations were made into their gender and age diversity, education, career, and other related experiences. The results showed that 95 per cent of directors are aged 40-plus (with most aged in their 50s and 60s), and only 5 per cent of directors are aged below 40. Cumulatively, this signals to users that our boards are becoming 'older'. Recently, the new Malaysian Companies Act 2016 has abolished the maximum age limit for directorship and has set the minimum age of eighteen (18). Previously, the maximum age of directors is seventy (70) under the Companies Act, 1965.

Limited empirical studies have been conducted on the effect of director's age and firm performance (see for example Abdullah \& Ku Ismail, 2013; Horvath \& Spirollari, 2012; Gavrea \& Stegerean, 2012) and the evidence has been mixed, which suggests the need for more studies, especially those conducted in Malaysia. This paper is proposing a more refined conceptual framework of the relationship between age diversity and the performance of corporate entity. As noted by Carter, Simkins \& Simpson (2003): 
“....given the emphasis being placed on board diversity as part of good corporate governance, the relationship between board diversity and shareholder value creation deserves both theoretical and empirical investigation" (p. 35).

Furthermore, as highlighted by Abdullah \& Ku Ismail (2013), board diversity can only be relevant in the business environment if it helps in enhancing the board's effectiveness; otherwise, it is just a 'tokenism' or a simple 'compliance'. In order to make diverse boards more effective, boards need to have a more egalitarian culture, which is one that elevates different voices, integrates contrasting insights, and welcomes conversations about diversity (Creary, McDonnell, Ghai \& Scruggs, 2019). Earlier studies have suffered from inconsistencies in measuring age diversity, whereby it has been based on average age of directors, while the basic concept of diversity looks at the inclusion as well. In addition to this, limited studies have also been conducted to examine the effect of director's' age diversity on firm performance especially in Malaysia, the exception are those by Abdullah \& Ku Ismail (2013) and Hassan \& Marimuthu (2016). With the unique ownership structure that exists within Malaysian corporations, distinct from those of developed countries, it is hoped that more studies are to be conducted in Malaysia. High ownership concentration, cross holdings and dominance of family-owned firms are among the characteristics of Malaysian firms contrary to developed countries which have dispersed ownership (Thillainathan, 1999).

\section{Literature Review}

\subsection{Firm Performance}

Previous studies conducted on firm performance have always related it to the corporate governance mechanisms. Among the common factors identified in previous literatures that affect firm performance are board size (see for example Jensen, 1993; Lipton and Lorsch, 1992; Hermalin and Weisbach, 2000; Zemzem and Kacem, 2014), non-executive directors, leadership structure, independent non-executive chairman (see for example Baysinger and Butler, 1985; Weisbach, 1988), firm size (see for example Ehikioya, 2009; Bernadette and Reid, 2003; Shukeri and Shaari, 2012; Abor, 2007) and diversification (see for example Gourlay and Seaton, 2004; Nachum, 2004; Santalo and Becerra, 2008).

There are mixed results regarding board size and performance. Empirical evidence indicates that the size of the board does matter as it affects the extent of monitoring, controlling and decision making in a company (Monks and Minow, 1995). Small boards are said to help in mitigating the effort problem and in becoming more effective (Jensen, 1993; and Lipton and Lorsch, 1992), but when they grow too big, boards become more symbolic rather than being a part of the management process (Hermalin and Weisbach, 2000). However, bigger boards may be constructive for some companies as they provide diversity that would help companies to secure critical resources and reduce environmental uncertainties. There is strong evidence that a small board of directors improves firms' performance (Zemzem and Kacem, 2014). According to Jensen (1993), smaller groups of boards are assumed to produce easier association and communication, co-operation and coordination while, Lipton and Lorsch, (1992) believed that small size of board may prevent free-riding and challenges of interest happening among members of boards. 
Non-executive directors are commonly known as 'non-employees' or outside directors are expected to bring independence into the board and add to the diversity of skills and expertise of the directors (Abdullah, 2004). Despite the advantages of having more non-executive directors on the board, prior studies documented mixed results pertaining to the relationship between the proportion of non-executive directors and firm performance. Choi et al. (2007) found a positive effect on the firm performance for Korean listed firms as a result of having independent directors on the company board. Similar finding was also found in China, ZongJun and Xiao-Lan (2006) revealed that a larger proportion of non-executive directors is negatively associated with the probability of distress. Several studies in Malaysia present contradictory evidence suggesting the advantages and disadvantages of having a high percentage of non-executive directors on boards. A study by Abdullah (2002) involving the KLSE (currently known as Bursa Malaysia) main board listed companies showed that Malaysian listed companies' boards that were dominated by non-executive independents had positive relationships with the presence of large shareholders, while negatively related to directors' shareholding and CEO duality. Meanwhile, other studies found that a higher percentage of non-executive directors had led to better auditing systems (Salleh et al., 2005), and improved financial reporting timeliness (Abdullah, 2006). However, other studies found that nonexecutive directors in Malaysia had not influenced the performance of Malaysian firms (Haniffa and Hudaib, 2006; Rahman and Mohamed Ali, 2006). The argument was based on the presumption that in most developing countries, including Malaysia, independent directors were not selected based on their expertise and experience, but more often for political reasons to legitimate business activities and for contacts and contracts (Haniffa and Hudaib, 2006). Hence, they do not function as monitors due to the lack of expertise and knowledge required to perform the role effectively.

Evidence on the relationship between CEO duality and firm performance are also mixed. Some studies provided evidence of a positive relationship between duality of roles and firm performance. In Malaysia, many studies show that duality roles have no impact on the performance of Malaysian firms (Rahman and Haniffa, 2005; Abdullah, 2006). Another study found that firms that had duality roles were not performing as well as their counterparts with separate board leadership (Rahman and Haniffa, 2005). In addition, firms dominated by a single person led to financial reports being issued much later than those with separation of roles (Abdullah, 2004).

Past research has also figured out the influence of non-executive and independent chairman on performance of corporations. For instance, Baysinger and Butler (1985), concluded that organizations perform better financially with outsiders who are placed as independent and non-executive dominated chairman as compared to insiders (executives) dominated, for nonexecutive chairman can act a vital part in creating various strategic decisions in the organization by keeping basic points. Outside independent chairman is assumed to act a vital role in controlling management compared to inside chairman (Weisbach, 1988).

Ehikioya (2009) had found that firm size has a significant positive relationship with performance since it can generate more revenue and high leverage. This is consistent with Bernadette and Reid (2003) which found that a trade-off exists between the firm's size and 
performance that is, increase (decrease) in firm size reduces (raises) the performance of the firm. Indirectly it is said that larger firm size has better source of ideas and knowledge but higher potential of communication conflicts. As reported by Shukeri and Shaari (2012) that large firms can utilize their resources efficiently and minimize downside risk, leading to improved firm performance. A study by Abor (2007) reported evidence in support of a positive relationship between board size and leverage. The study argued that large boards with superior monitoring ability pursue higher leverage to raise the value of the firm.

Evidence also indicate that diversified strategy could be used to enhance firm performance, among them (Gourlay and Seaton, 2004; Nachum, 2004). Diversified strategy is identified if firms have operations in more than one industry (Santalo and Becerra, 2008). Kim, Hwang and Burgers (1989) contend that diversification may improve firm performance through various products or services in generating the revenues. Nachum (2004) on the other hand advocates that firms in developing countries would be better off by adopting diversified strategy due to the presence of the commodity sectors.

\subsection{Board of Directors as Corporate Governance Mechanism}

Under the two-tier board structure such as the ones practiced in countries such as Germany, Japan and Netherlands require the board of supervisor to appoint the board of management. The management board performs the executive functions, while the supervisory board is responsible in monitoring the management board. Meanwhile, under the unitary board structure as practiced in countries such as Malaysia and many other countries, executives and other non-executive directors sit on the same board. Therefore, the board of directors is not only responsible to communicate to stakeholders, but they are also responsible in dealing with matters relating to strategy, performance, planning, resources and standards of conduct of the organization.

Earlier literatures on the board of directors mostly discuss according to the agency perspectives. This theory views the responsibility of the directors is to provide monitoring function to the managers to mitigate the agency cost within an entity (Jensen \& Meckling, 1976; Fama, 1980; Fama \& Jensen, 1983). The theory is because shareholders have very minimal involvement in the corporate entity, they have limited information on managers' actions and decisions. On the other hand, managers have the opportunity and motivation to use the firm's resources for their own benefits at the expense of shareholdlers. Therefore, the directors are responsible to monitor and control the managers from taking any actions and making decisions that may have a negative impact on the shareholders. The effectiveness of directors under the agency theory focuses on the independence of the directors in performing their oversight roles. Based on the theory, the board is suggested to include directors who are independent from the management, company, and shareholders. The concept of non-executive directors relates to this theory. Furthermore, many reforms on corporate governance in the early 2000s have focused on enhancing the independence of the board (and its sub-committee). For example, the Sarbanes Oxley Act (2002) in the U.S and the Malaysian Code on Corporate Governance (2002), both focus on defining and appointing independent directors, among other things. 
In contrast, the stewardship theory views managers as good stewards who are trustworthy and work diligently (Donaldson \& Davis, 1994). The managers are argued to act in the best interest of shareholders, in order to achieve higher personal outcomes of achievement, affiliation and self-actualization (Davis et al., 1997). Therefore, board of directors comprising mostly of internal personnel has more intimate knowledge of the organizational operations and a deeper commitment to the success of the firm. Based on these two theories (i.e., agency and stewardship theory), it can be concluded that boards should be consisted of a balanced combination of independent and executive directors.

Meanwhile, the resource dependence theory views directors as resource providers that supplies legitimacy, advice and counsel to the firms (Hillman et al., 2000; Hilman \& Dalziel, 2003; Pfeffer \& Salancik, 1978). The theory looks beyond the monitoring roles of the directors by focusing on broader aspects of directors' responsibility. The board is viewed as a mechanism for managing external dependencies, reducing environmental uncertainty, and reducing the transaction costs associated with environmental interdependency (Pfeffer \& Salancik, 1978). Therefore, based on the theory, the directors should be appointed among individuals who can bring a difference to the company.

\subsection{Board's Diversity}

Board diversity has been defined in several ways, but in general it can be defined as having directors with different characteristics. The basic concept of diversity can be related to representation (Basaglio, 2012), whereby the board should be represented by a mixed of people. However, as highlighted by Basaglio (2012), the benefits of diversity need to be appreciated based on skills each individual possesses through different career paths, backgrounds and experiences in their life. Kang, Cheng \& Gray (2007) defiined board diversity as a variety in composition of the board of directors. Two general classifications of diversity are observable (demographic) such as gender, age, race and ethnicity and the non-observable (cognitive) such as knowledge, values, perception and personality (Erhardt, Werbel \& Shrader, 2003). Demographics characteristics are claimed to be associated with cognitive bases, value and perceptions that will influence the decision-making process, and thus quality. Dijk \& Engen (2013) classifies diversity into variety, separation and disparity, where variety has been related to information and decision making, separation has been related to social categorization and disparity has been related to status-related processes. The fact that the society itself is heterogeneous thus, the board should reflect that society. A diverse board allows for representation of not only shareholders but also other stakeholders. Simply, board diversity refers to having a variety of members on the board (Van der Walt \& Ingley, 2003). In general, board diversity has been argued to enhance the understanding of the market, increases creativity and innovation and creates effective problem-solving (Carter et al., 2003). Furthermore, diverse members might also ask questions that would not be queried by homogenous board (Arfken et al., 2004). As claimed by Harjoto, Laksmana \& Lee (2015), it allows the board to provide a wide range of knowledge and skills and at the same time, increases firm's ability to recognize the need of the stakeholders. 


\subsection{Age and Generations}

Age has been recognized as one distinct characteristic among individuals. Researchers in many areas have classified individuals based on generations, however, no consensus (as yet) exists on the lines dividing one generation to the other. Furthermore, each generation has also been related to unique characteristics which are shaped by the unique events, settings and innovations of its time-period. Psychological differences between generations is not a new concept. People born before mid-1940s are named as traditionalist, also known as the "Silent Generation" because children of this era were expected to be seen and not heard. Traditionalists were born during the most devastating economical event in our nation's history, so they were expected to have a tough life. Due to the economic and political uncertainty, traditionalists were led to be hard-working, respectful of authority and loyal (Danklefsen \& Meyer, 2015). Hence, they consider work as a privilege and this group is more likely to have had a lifetime career with one company. In other words, they are less likely to change jobs to advance their careers than those of the younger generations, but they expect the same loyalty in return (Kane, 2017). Besides that, being raised in a paternalistic environment, the silent generation was taught to respect authority, and they tend to be good team-players. Even though this generation may be less technologically-adept than younger generations, but they often have great one-on-one interpersonal skills because they are more accustomed to dealing with people eye-to-eye (Kane, 2017).

Meanwhile, those born in the mid-1940s to mid-1960s are known as baby-boomers. Baby-boomers got their names because of an increased mark in the birth rate during the time in which they were born (Danklefsen \& Meyer, 2015). The Boomer generation has many significant events that affect their worldview. They grew up in a time when the nation was optimistic, following the independence of the nation. Like traditionalists, boomers are known for their hard-work, idealism and commitment to peace in the workplace (Danklefsen \& Meyer, 2015). They are more optimistic and are open to change than the prior generation, but they are also responsible for the "Me Generation," (a.k.a Generation-Y) with its pursuit of personal gratification, which often shows up as a sense of entitlement in today's workforce (Kane,2017). However, boomers are also self-motivated and show long-term commitment (Danklefsen \& Meyer, 2015).

Gen-Xers (those born in mid-1960s to early 1980s) are known for being entrepreneurs, which fits them well due to their flexible and self-reliant nature (Danklefsen \& Meyer, 2015). Gen-Xers are the first generation that grow up comfortably with technology. Gen-X is a complex generation and some people even regard Gen-Xers as self-indulgent (Jennings, 2000). Professionally, this generation is known to question authority and to be skeptical in general. This may be because they have witnessed years of corporate downsizing, the failure of many technology businesses and the collapse of even large, established companies, hence it should come as no surprise that Gen-Xers might approach their work and careers very differently than their predecessors (Jennings, 2000). Gen-Xers expect to have multiple employers throughout their careers and maybe even multiple careers (Danklefsen \& Meyer, 2015), hence job-hopping is a normal, accepted method of career advancement for Gen-Xers (Jennings, 2000). The two generations (i.e., baby boomers \& Gen-X) also have different communication-styles, whereby 
Gen-Xers tend to be more informal and direct. They rely heavily on e-mail and may not have the analytical abilities and long-term perspective that their senior colleagues possess (Jennings, 2000).

The next generation, Generation- $Y$ can also be called "Generation Me" because they have been taught to put themselves first. Unlike the baby-boomers, this generation is not self-absorbed, but they are self-important (Williams, 2013). This generation which is also commonly known as the 'millennials', grew up in a time when the largest number of homes had internet connection, hence this is most attributable to the fact that this generation grew up with email, Internet, cell phones and the ability to access information almost anywhere at any time (Danklefsen \& Meyer, 2015). In other words, they are multi-taskers who are tech-savvy. Gen-Y has grown up naturally collaborative, talented and open-minded, flexible and they thrive on social media, all characteristics well-suited to the new economy.

Generation-Z (those born starting in the mid-90s to the early '00s) are poised to be somewhat different from the millennials. This generation tend to be independent, as a result of growing up in a healthier economy. Despite their obvious technology proficiency, Gen-Zers seem to prefer in-person to online interactions and are accustomed to engaging with friends all over the world, so they are well-prepared for a global business environment.

\section{Theoretical Framework and Hypothesis Development}

The association between board diversity and firm performance can be explained theoretically through the agency, resource dependence and stakeholder theories. As agents, boards play an important role as described under the agency theory in reducing the information asymmetry between owners and managers of the firm. Under the resource dependence theory, the board is viewed as an essential link between the firm and the external resources that are essential in maximizing firm performance (Pfeffer 1973; Pfeffer \& Salancik, 1978) and is regarded as an important resource for a firm because it provides a link with the external environment (Hillman et al., 2000; Palmer \& Barber, 2001). Meanwhile, the stakeholder theory argues that firms explicitly and implicitly have contracts with various social constituents and are expected to honor all those contracts (Freeman 1983, 1984; Donaldson \& Preston, 1995; Jones, 1995). The firm's shareholders are regarded as one of the many stakeholders whom the board needs to consider in their decision-making process (Clarkson, 1995; Donaldson \& Preston, 1995; Jones, 1995; Wood \& Jones, 1995; Mitchell et al., 1997), hence the board works hard to please these shareholders. As capital providers to the firm, shareholders expect their investments will enhance their wealth which can be achieved through better firm performance. It is widely accepted that the role of board of directors under the unitary structure requires the board to have interdependence roles. The board is not only responsible to monitor the management, but also to actively be involved in the strategic decision-making process (Hambrick \& Mason, 1984). This duality role can enhance the performance of the company, if effectively performed. Even though some decisions are under the responsibility of CEO, the board still has the ultimate power over the decisions. Upper Echelon theory by Hambrick \& Mason (1984) suggests that the firm performance is affected by the top management and therefore, 
characteristics of top management influence the decisions and actions of the firm. Hence, an effective board can result in better shareholders' wealth.

The effect of director's age diversity on firm performance can be related to high quality decision by the board of directors. Houle (1990) argued that older members can provide experience, wisdom and economic resources, middle-aged member carries major positions of active responsibilities in corporations and society, whilst young members have the energy and drive to succeed. Young directors are also expected to bring new perspectives to the firm (Abdullah \& Ku Ismail, 2013). On the other hand, directors of the same age groups may have similar information, experience, and beliefs; and therefore, having different age groups will help the board to have diverse information. Therefore, board with disperse age may have more perspective on an issue which enhance board's discussion and quality decision. Furthermore, age is postulated detrimental to risk-taking. Vroom \& Pahl (1971) found that older managers are more likely to avoid risky decisions. While risk taking is essential to performance, older boards are believed to have lower performance (Hassan \& Marimuthu, 2016). Horvath \& Spirollari (2012) argued that younger members are more willing to bear more risk and to undertake major structural changes to improve prospects. However, Hambrick \& Mason (1984) argued that young managers are more inclined to adopt risky strategies. At the same time, the need for diversity age group can be related to the possibility that the leadership and the decision-making styles of the board might be biased towards the same age group (Abdullah $\& \mathrm{Ku}$ Ismail, 2013). As the workforce, customers and others have become the new generation, the board should also be comprised of this generation. Having the same age level may make the board insensitive to different age levels. Furthermore, younger members can also be related to being more independent due to low attachment to management or main shareholders.

Earlier studies have shown mixed findings on the effect of director's' age on firm performance. A study conducted in Sweden by Pesämaa, Klaesson, Haahti (2008), examining the relationship between board members' average age and its effect on performance was proven to be insignificant. Using a sample of 136 S\&P 500 index companies in 2005-2009, Horvath \& Spirollari (2012) found a negative relationship between age and firm value. Meanwhile, using 46 firms listed on Bucharest Stock Exchange in 2010, Gavrea et al. (2012) found insignificant relationship with ROE and ROA. In Malaysia, Abdullah \& Ku Ismail (2013) found significant negative relationship between older board and ROA, but is insignificant with Tobin's Q. Another Malaysian study by Abdul Latif et. al (2013) found a negative relationship between directors' age and firm value. In contrast, Hassan \& Marimuthu (2016) found a significant positive relationship between older board with ROE and Tobin's Q. However, even though it has a positive relationship, age is found to be insignificant with ROA. The mixed findings may be probably due to the weaknesses in measuring age diversity. Most of these studies use average age of board of directors (see for example Horvath \& Spirollari, 2012; Gavrea et al., 2012). This has been replicated by Malaysian studies by Abdul Latif et. al. (2013) and Hassan \& Marimuthu (2016). In contrast, Abdullah \& Ku Ismail (2013) uses dummy measurement where 1 , if the average age of directors is less than 60 years, and 0 if otherwise. The rationale is that directors whose nearing their retirement is considered to be "stale". The use of average directors' age is inconsistent with diversity arguments which focus on the imclusion of different 
age of individuals on the board of directors. Meanwhile, Diepen (2015) measures age diversity based on percentage of directors in a specific age group; till 40, 41 till 50, 51 till 60, 61 till 70 and above 71. Therefore, following Diepen (2015) and another earlier study by Kang, Cheng \& Gray (2007), this study proposes that in order to examine the effect of director's' age diversity, directors' age should be separated to different unique groups. Both studies use five (5) age brackets in classifying directors' age diversity: under 41, between 41 to 50 , between 51 to 60 , between 61 to 70 and over 71. Assuming a company has directors in three (3) cohorts, the measurement should be 3 over 5. However, in the study by Diepen (2015), it examines the effect of the percentage of directors in each cohort, not diversity in cohorts.

H1: Diversity in age of directors is positively related to firm performance.

\section{Conclusion}

Board of directors is the highest governance mechanism in the corporate structure. As shareholders' representatives, the board is responsible to not only monitor the management, but also to be involved in strategic decision-making with the goal of enhancing shareholders' wealth. Earlier studies on board of directors focus more on the independence of directors, however recently, there are increasing interests by the government, public and researchers on the need for diversity in board members. The resource dependence theory views directors as a mechanism in managing dependencies of company other than external factors, hence each unique individual director will bring necessary network, knowledge, and connections to enhance firm's performance. Diversity in age has long been recognized in social studies whereby individuals from different generations are believed to possess different characteristics, while same generations have common characteristics. Therefore, board of directors from diversify generations is expected to contribute to more quality decision. However, there has been no conclusive empirical evidence on the influence of age diversity on corporate performance, which is possibly due to the failure in recognizing each generation's effect. Earlier studies measure director's' age diversity based on average age of board members which is inconsistent with the diversity concept. Hence, this study proposes that in order to examine the effect of age diversity, the measurement should be based on the inclusion of directors with different age cohorts. This measurement is consistent with social/demographic studies which class people into generations. While no consensus exists on the cutting line of one generation to the next, five (5) age cohorts are suggested to be used in the future studies (i.e., under 40, 40-49, 50-59, 60-69 and 70 over old). The measurement is more suitable in the study of diversity.

\section{Acknowledgments}

This study is funded by Universiti Utara Malaysia under the Research Generation Grant 2017.

\section{References}

Abor, J. (2007). Corporate governance and financing decisions of Ghanaian listed firms. Corporate Governance: The International Journal of Business in Society, 7(1), 83-92. https://doi.org/10.1108/14720700710727131 
Abdul Latif, R., Kamardin, H., Mohd, K. N. T. \& Che Adam, N. (2013). Multiple directorships, board characteristics and firm performance in Malaysia. Management Science, 3(2), 105-111.

Abdullah, S. N. (2002). Audit committee establishment in Malaysia: Some insights prior to the Asian 1997 financial crisis. Utara Management Review, 3(1), 1-17.

Abdullah, S. N. (2004). Board composition, CEO duality and performance among Malaysian listed companies. Corporate Governance International Journal of Business in Society, 4, 47-61. https://doi.org/10.1108/14720700410558871

Abdullah, S. N. (2006). Board composition, audit committee and timeline of corporate financial reports in Malaysia. Journal of Corporate Ownership \& Control, 4(2), 33-45. https://doi.org/10.22495/cocv4i2p3

Abdullah, S. N., \& Ismail, K. N. I. K. （2013）. Gender, ethnic and age diversity of the boards of large Malaysian firms and performance. Jurnal Pengurusan, 38, 27-40. https://doi.org/10.17576/pengurusan-2013-38-03

Abdul Rahman, R. \& Haniffa, R. (2005). The effect of role duality on corporate performance in Malaysia. Corporate Ownership and Control, 2(2), 40-47. https://doi.org/1 0.22495/cocv2i2p4

Abdul Rahman, R. \& Mohamed Ali, F. H. (2006). Board, audit committee, culture and earnings management: Malaysian evidence. Managerial Auditing Journal, 21(7), 783-804. https://doi.org/10.1108/02686900610680549

Arfken, D. E., Bellar, S. L. \& Helms, M. M. (2004). The ultimate glass ceiling revisited: the presence of women on corporate boards. Journal of Business Ethics, 50(2), 177-186. https://doi.org/10.1023/B:BUSI.0000022125.95758.98

Barret, A. (2017). Age diversity within boards of directors of the S\&P 500 companies. In Investor Responsibility Research Center Institute (IRRCi). Retrieved from https://irrcinstitute.org/wp-content/uploads/2017/03/FINAL-Age-Diversity-Study-March-201 7.pdf

Basaglia, S. (2012). The different facets of diversity in boards of directors. In SDA Bocconi School of Management. Retrieved from http://www.unibocconi.eu/wps/allegatiCTP/8-\%20abstract_WBr.pdf.

Baysinger, B. D. \& Butler, H. N. (1985). Corporate governance and the board of directors' performance: effects of changes in board composition. Journal of Law, Economics, \& Organization, 1, 101-124.

Bernama. (2020, January 11). Malaysian corporate boards lack diversity. Borneo Post Online. Retrieved from: https://www.theborneopost.com/2020/01/11/msian-corporate-boards-lack-diversity/ 
Carter, D. A., Simkins, B. J. \& Simpson, W. G. (2003). Corporate governance, board diversity, and firm value. The Financial Review, February 2003. Retrieved from: https://ssrn.com/abstract=344042.

Choi, J. J., Park, S. W., \& Yoo, S. S. (2007). The value of outside directors: Evidence from corporate governance reform in Korea. Journal of Financial and Quantitative Analysis, 42, 941-962. https://doi.org/10.1017/S0022109000003458

Clarkson, M. (1995). A stakeholder framework for analyzing and evaluating corporate social performance. Academy of Management Review, 20, 92-117. https://doi.org/10.5465/amr.1995.9503271994

Creary, S.J., McDonnell, M.H., Ghai, S. \& Scruggs, J. (2019). When and Why Diversity Improves Your Board's Performance. Harvard Business Review. Retrieved from: https://hbr.org/2019/03/when-and-why-diversity-improves-your-boards-performance

Danklefsen, E. \& Meyer, C. (2015). Generational ethics: are we really that different? Retrieved from:

https:/www.njcpa.org/stay-informed/topics/article/2015/11/19/generational-ethics-are-we-rea lly-that-different.

Davis, J. H., Schoorman, F. D., \& Donaldson, L. (1997). Toward a stewardship theory of management. Academy of Management Review, 22(1), 20-47. https://doi.org/10.2307/259223

Donaldson, T. \& Preston, L. (1995). The stakeholder theory of the modern corporation: concepts, evidence and implications. Academy of Management Review, 20, 65-91. https://doi.org/10.5465/amr.1995.9503271992

Donaldson, L., \& Davis, J. H. (1991). Stewardship theory or agency theory: CEO governance and shareholder returns. Australian Journal of Management, 16(1), 49-64. https://doi.org/10.1177/031289629101600103

Dijk, H. V. \& Engen, M. L. (2013). A status perspective on the consequences of work group diversity. Journal of Occupational and Organizational Psychology, Special Issue, 86(2), 123-282. https://doi.org/10.1111/joop.12014

Diepen, N. (201). The effect of gender, age and nationality diversity on company performance - Evidence from the Netherlands. Paper presented at the 5th IBA Bachelor Thesis Conference, July 2nd, 2015, Enschede, The Netherlands.

Erhardt, N. L., Werbel, J.D. \& Shrader, C. B. (2003). Board of director diversity and firm performance. Corporate Governance: An International Review, 11(2), 102-111. https://doi.org/10.1111/1467-8683.00011

Ehikioya, B. (2009). Corporate governance structure and firm performance in developing economies: evidence from Nigeria. Corporate Governance: The International Journal of Business in Society, 9(3), 231-243. https://doi.org/10.1108/14720700910964307 
Fama, E. (1980). Agency problems and the theory of the firm. The Journal of Political Economy, 88(2), 288-307. https://doi.org/10.1086/260866

Fama, E. F., \& Jensen, M. C. (1983). Separation of ownership and control. Journal of Law and Economics, 26, 301-325. https://doi.org/10.1086/467037

Freeman, R. E. (1983). Strategic management: A stakeholder approach. Advances in Strategic Management, 1, 31-60. https://doi.org/10.1017/CBO9781139192675.003

Freeman, R. E. (1984). Strategic management: a stakeholder approach. New York: Basic Books.

Gavrea, C., Stegerean, R. \& Marin, A. (2012). Corporate board structure and organizational performance: evidence from Romanian firms. Retrieve from: https://ideas.repec.org/a/bbn/journ1/2012_1_2_gavrea.html.

Goyal, R., Kakabadse, N. \& Kakabadse, A. (2019). Improving corporate governance with functional diversity on FTSE 350 boards: directors' perspective. Journal of Capital Markets Studies, 3(2), 113-136. https://doi.org/10.1108/JCMS-09-2019-0044

Gourlay, A. \& Seaton, J. S. (2004). The determinants of firm diversification in UK quoted companies. Applied Economics, 36(18), 2059-2071. https://doi.org/10.1080/0003684042000295610

Hambrick, D. C. and Mason, P. A. (1984). Upper Echelons: The organization as a reflection of its top managers. Academy of Management Review, 9, 193-206. https://doi.org/10.5465/amr.1984.4277628

Harjoto, M., Laksmana, I. \& Lee, R. (2015). Board diversity and corporate social responsibility. Journal of Business Ethics, 132, 641-660. https://doi.org/10.1007/s10551-014-2343-0

Hassan, R. \& Marimuthu, M. (2016). Corporate governance, board diversity, and firm value: examining large companies using panel data. Economics Bulletin, 36(3, A170.

Hillman, A. J., Canella, A. A. \& Paetzold, R. L. (2000). The resource dependence role of corporate directors: Strategic adaptation of board composition in response to environmental change. Journal of Management Studies, 37, 235-255. https://doi.org/10.1111/1467-6486.00179

Hoffman, L. R. \& Maier, N. R. F. (1961). Quality and acceptance of problem solutions by members of homogeneous and heterogeneous groups. The Journal of Abnormal and Social Psychology, 62(2), 401-407. https://doi.org/10.1037/h0044025

Horvath, R. \& Spirollari, P. (2012). Do the board of directors' characteristics influence firm's performance? The U.S. evidence. Prague Economic Papers, 4, 470-486. https://doi.org/10.18267/j.pep.435

Houle, C. O. (1990). Who should be on your board? Non-profit World, 8, 33-35. 
Huse, M., \& Rindova, V. P. (2001). Stakeholders' expectations of board roles: The case of subsidiary boards. Journal of Management and Governance, 5, 153-178. https://doi.org/10.1023/A:1013017909067

Jennings, A. T. (2000). Hiring generation X. February 1, (2000). Retrieved from: https://www.journalofaccountancy.com/issues/2000/feb/hiringgenerationx.html.

Jensen, M. C. (1993). The modern industrial revolution, exit, and the failure of internal control systems. Journal of Finance, 831-880. https://doi.org/10.1111/j.1540-6261.1993.tb04022.x

Jensen, M. C. \& Meckling, W. H. (1976). Theory of the firm: managerial behavior, agency costs and ownership structure. Journal of Financial Economics, 3, 305-360. https://doi.org/10.1016/0304-405X(76)90026-X

Jones, T. M. (1995). Instrumental stakeholder theory: A synthesis of ethics and economics. Academy of Management Review, 20(2), 404-437. https://doi.org/10.5465/amr.1995.9507312924

Kane, S. (2017). Common characteristics of traditionalists (the silent generation) how the silent generation can benefit your law firm, 20 March 2017, Legal Careers. Retrieved from: https://www.thebalance.com/workplace-characteristics-silent-generation-2164692.

Kang, H., Cheng, M. \& Gray, S. J. (2007). Corporate governance and board composition: diversity and independence of Australian boards. Corporate Governance: An International Review, 15(2), 194-207. https://doi.org/10.1111/j.1467-8683.2007.00554.x

Kim, W. C., Hwang, P. \& Burgers, W. P. (1989). Global diversification strategy and corporate profit performance. Strategic Management Journal, 10(1), 45-57. https://doi.org/10.1002/smj.4250100105

Levit, A. (2015). Make way for generation Z. March 28, 2015. The New York Times. Retrieved from: https://www.nytimes.com/2015/03/29/jobs/make-way-for-generation-z.html

Lipton, M. \& Lorsch, J.W. (1992). A modest proposal for improved corporate governance. Business Lawyer, 48, 59-77.

Malaysian Code on Corporate Governance. (2017). Kuala Lumpur: Securities Commission.

Miliken, F. \& Martin, L. (1996). Searching for common threads: understanding the multiple effects of diversity in organizational groups. Academy of Management Review, 21(2), 402-433. https://doi.org/10.5465/amr.1996.9605060217

Minichilli, A., Zattoni, A., \& Zona, F. (2009). Making boards effective: An empirical examination of board task performance. British Journal of Management, 20(1), 55-74. https://doi.org/10.1111/j.1467-8551.2008.00591.x

Mitchell, R., Agle, B. \& Wood, W. (1997). Towards a theory of stakeholder identification and salience: defining the principle of who and what really counts. Academy of Management Review, 22 (4): 853-886. https://doi.org/10.2307/259247 
Mohd Saleh, N., Mohd Iskandar, T. \& Rahmat, M. M. (2005). Earnings management and board characteristics: Evidence from Malaysia. Jurnal Pengurusan, 24, 77-103. https://doi.org/10.17576/pengurusan-2005-24-04

Monks, R. A. G \& Minow, N. (1995). Corporate Governance, 5th Edition.

Nachum, L. (2004). Geographic and industrial diversification of developing country firms. Journal of Management Studies, 41, 273-294. https://doi.org/10.1111/j.1467-6486.2004.00432.x

Palmer, D. \& Barber, B. M. (2001). Challengers, elites, and owning families: a social class theory of corporate acquisitions in the 1960s. Administrative Science Quarterly, 46, 87-120. https://doi.org/10.2307/2667126

Pechersky, A. (2016). Diversity in board of directors: Review of diversity as a factor to enhance board performance. Studia Commercialia Bratislavensia, 9(33), 88-101. https://doi.org/10.1515/stcb-2016-0009

Pesämaa, O; Klaesson, J. \& Haahti, A. (2008). Board of directors and its effect on performance: the case of Gnosjö region in Sweden. Innovative Marketing, 4(4), 77-85

Pfeffer, J. (1973). Size, composition and function of hospital boards of directors: a study of organization environment linkage. Administrative Science Quarterly, 18, 349-363. https://doi.org/10.2307/2391668

Pfeffer, J. \& Salancik, G. R. (1978). The external control of organizations: A resource dependence perspective. New York: Harper and Row.

Santalo, J. \& Becerra, M. (2008). Competition from specialized firms and the diversificationperformance linkage. The Journal of Finance, 63(2). April: 851-883. https://doi.org/10.1111/j.1540-6261.2008.01333.x

Sarbanes Oxley Act. (2002). Retrieved from: https://www.sec.gov/about/laws/soa2002.pdf.

Shukeri, S. W., Shin, O. W. \& Shaari, M. S. (2012). Do board of characteristics affect firm performance? Evidence from Malaysian public listed firms. International Business Research, 5(9), 120-127. https://doi.org/10.5539/ibr.v5n9p120

Thillainathan, R. (1999). Corporate governance \& restructuring in Malaysia - A review of markets, mechanisms, agents \& the legal infrastructure. World Bank/OECD Survey of Corporate Governance.

Weisbach, M. S. (1988). Outside directors and CEO turnover. Journal of Financial Economics, 20, 431-460. https://doi.org/10.1016/0304-405X(88)90053-0

Williams, R. (2013). Is gen Y becoming the new "lost generation"? Ecomomic prospects for millennials look dim. Posted Apr 09, 2013, Retrieved from: https://www.psychologytoday.com/blog/wired-success/201304/is-gen-y-becoming-the-new-1 ost-generation. 
Wood, D. \& Jones, R. (1995). Stakeholder mismatching: a theoretical problem in empirical research on corporate social performance. The International Journal of Organizational Analysis, 3(3), 229-267. https://doi.org/10.1108/eb028831

Van der Walt, N. \& Ingley, C. (2003). Board dynamics and the influence of professional background, gender and ethnic diversity of directors. Corporate Governance: An International Review, 11(3), July: 218-234. https://doi.org/10.1111/1467-8683.00320

Vroom, V. H. \& Pahl, B. (1971). Relationship between age and risk taking among managers. Journal of Applied Psychology, 55(5) October: 399-405. https://doi.org/10.1037/h0031776

Zemzem, A. \& Kacem, O. (2014). Risk management, board characteristics and performance in the Tunisian lending institutions. International Journal of Finance \& Banking Studies, 3(1). https://doi.org/10.20525/ijfbs.v3i1.179

\section{Copyrights}

Copyright for this article is retained by the author(s), with first publication rights granted to the journal.

This is an open-access article distributed under the terms and conditions of the Creative Commons Attribution license (http://creativecommons.org/licenses/by/4.0/) 